\title{
SYSTEMATIC REVIEW OF SUSTAINABLE DESIGN APPROACH FOR MOSQUE
}

| Received September 19 2021 | Accepted November 24 2021 | Available online December $30^{\text {th }} 2021$ | DOI http://dx. doi.org/10.18860/jia.v6i4.14016 |

\section{Mohamad Ikhram Mat Sobri}

Department of Architecture,

Faculty of Design and Architecture, Universit Putra Malaysia, Jalan UPM, 43400 Serdang,

Se-langor, Malaysia

\section{*Sumarni Ismail}

Department of Architecture,

Faculty of Design and Architecture, Universit

Putra Malaysia, Jalan UPM, 43400 Serdang

Se-langor, Malaysia

e-mail:

sumarni.upm@gmail.com

*Corresponding Author.

\section{Azmal Sabil,}

Department of Architecture,

Faculty of Civil Engineering and Built

Environment,

University Tun Hussein Onn Malaysia, 86400

Parit Raja, Johor, Malaysia

\section{Hanita Yusof}

Department of Architecture,

Faculty ofEngineering and Built Environment,

Uni-versity Tun Hussein Onn Malaysia, 86400,

Parit Raja, Johor, Malaysia Civil

\section{Nayeem Asif}

Kulliyyah of Architecture and Environmental

De-sign, International Islamic University

Malaysia Gombak, Malaysia

\section{Ernaning Setiyowati}

Architecture Department

Universitas Islam Negeri Maulana Malik Ibrahim

Malang

Indonesia

\section{ABSTRACT}

As one of the prominent public spaces for the community, Mosque is consid-ered one of the high energy consumption buildings. Many modern mosques are designed and built without respecting the contextual environment, re-sulting in a nonenvironmental friendly Mosque. In Malaysia, the operating cost of mosques is majorly relying on public funds, and statistically are high specifically for electricity usage. Due to the use of air conditioners in cooling down the huge prayer hall due to the non-environmental design consideration. Hence, it is crucial to justify sustainable design approaches in mosques to develop environmentally friendly mosques. On the other side, the environmen-tally friendly mosque design is important as one of the monumental Islamic symbols that shall manifest Islam's values and philosophies towards the ben-efit of 'Alam' (world). The main objective of this study is to analyze the princi-ples of Islamic methods in attaining the attributes of sustainable mosque design. It systematically reviews the existing publications to discover the concepts, definitions, and issues regarding the sustainable design approach-es for Mosque. Based on the conducted reviews, sustainable design strate-gies for mosques are suggested at the end of this paper. The Mosque can use some renewable technologies to save energy and be concerned about the climate condition for its design. Furthermore, it can also use sustainable materials, use natural ventilation and daylighting to provide good indoor air quality, and be concerned about the social life of Muslim's religious activities.

\section{KEYWORDS:}

Mosque, Sustainable Design, Islamic Principles

\section{INTRODUCTION}

The Mosque's architecture is an influential factor that defines the overall experience of worshippers inside and outside the Mosque. It addresses not only the planned architectural aspect of a mosque but also the practical and sustainability qualities of a mosque. In Islamic societies, mosques are important institution buildings because they accommodate spiritual, social, and educational activities. The beneficial influence of mosques on development in the idea of sustainability in culture is unquestionable. From the practical Mosque, the degree of strength of Muslim harmony could be created. Still, it started to decline due to a lack of sustainable design into design of Mosque that could not meet the diverse needs of society [1]. Therefore, building a sustainable and standard mosque is necessary to fulfill and enhance the function that can adapt to the essential human beings. In this context, the design of a sustainable mosque needs to concern the environmental strategies that provide the optimal use of resources; energy, climate, and building materials. They also need to be concerned about indoor air quality and have a flexible design [2]. The space design should also be included in cutting-edge mosque strategy for the wellness and comfort of users inside the mosques. Moreover, sustainability also has to concern the economic and social dimensions. Social sustainability refers to social equity, well-being, and quality of life [3].

Therefore, through using and implementing the sustainability approaches, the productivity of activities will be reshaped. Moreover, the area used in a spiritual building will be used because ignorance of the environmental aspect will impact the user's experience 
in negative conditions. Hence, the functional quality of design implementation in mosques and building design can be constructed for the Muslim community through the green and sustainable approaches of Mosque.

\section{Sustainability of Mosque Design in the Global Context}

International organizations have emphasized that sustainable design is important to ensure an acceptable quality of life for our planet's present occupants and future generations. Traditionally, mosques have more functions than just being a place of worship, especially in the Middle East [4]. A mosque is not only used to perform the prayer, but also is a place for society to create economic, educational, and social harmony. Thus, both the Mosque and its surroundings work together symbiotically. Therefore, a green and sustainable Mosque can be defined as a multifunctional community one-stop center that uses places, is accessible for the community, is respectful to the environment geographically, supports local business, and increases civic engagement and information discovery. The first Mosque founded in Madinah by Prophet is an excellent example of environmentally friendly practices and shows the ideal character of sustainable and green architecture mosque [5]. Even though the Mosque's architecture and construction technologies may not be common in modern times, the values of such sustainable practices are implemented in the design planning of the Mosque. However, few kinds of research on environmental sustainability have been conducted focusing on the energy consumption of mosques. It has been discovered that mosques consume a large amount of energy that is not sustainable.

\section{Sustainability of Mosque Design in Malaysia Contex}

In Malaysian history, the country's heritage was rich in mosque architecture. Mosques in many Malaysian provinces displayed various designs and used different elements to construct many mosques that reflected the country's culture and people. Provinces like Terengganu, Melaka, and others have very famous traditional mosques. Researchers attempted many studies to document and record the physical planning drawings to preserve the country's heritage.

During Islam's early arrival in Malaysia compared to the mosques in the Middle East countries, the architecture of the Malay Peninsula mosque was plain with no clear features [6]. One big problem is that architects cannot take the requisite chances to experiment with new forms or approaches when designing mosque architecture. Moreover, as decision-makers, it is also imperative for the public, or the owners, to understand the need to open and embrace another view of Islamic architecture. Therefore, a more inclusive, safe, and egalitarian solution is a serious need for all new mosque buildings and other non-religious buildings.
Malaysia is situated near the equator with a tropical atmosphere and an average temperature of $270 \mathrm{C}$ [7]. For designers, the high humidity and temperature level pose a problem in designing a space because certain situations react to the needs of the inhabitants. For example, a building with low insulation and ventilation will affect discomfort for the visitors. Therefore, designers need to use a green and sustainable approach for mosque construction to achieve and assume comfort inside the Mosque and ensure natural ventilation through the building. This study systematically reviews the existing publications to discover the concepts, definitions, and issues regarding the sustainable design approaches for mosques. The main objective is to analyze the principles of Islamic methods in attaining the attributes of sustainable mosque design.

\section{METHODOLOGY}

Recently, systematic reviews have become an essential approach for selecting, critiquing, and summarizing existing text materials or literature reliably and accurately on specific topics or objectives, as mentioned. The research depended on browsing articles and publications on multiple platforms. A general procedure of looking up terms such as "sustainable mosque", "green architecture", "sustainability", "innovative design", and "Islamic architecture" was used, with keeping in mind to filter out the results to only publications done between the years of 2010 and 2020, and preference for Malaysian based studies and other countries. Several articles were shortlisted based on their relevance to the study's objective.

The content of the selected articles was then analyzed by adapting the content analysis techniques, consisting of manifest analysis and latent analysis. The manifest analysis technique was adapted to a sustainable design approach for mosques. In a manifest analysis, the researcher describes what the informants say, stays very close to the text, uses the words themselves, and describes the visible and obvious in the text [8]. In the context of this paper, the prime ideas of the sustainable design approach of mosques are classified based on the content of selected articles. On top of that, the latent analysis technique was applied to recommend the sustainable Mosque's design strategies. Finally, lent analysis is extended to an interpretive level in which the researcher seeks to find the underlying meaning [8]. The classified sustainable design approach for mosques will be interpreted in contemporary mosque design.

\section{RESULT AND DISCUSSION}

\section{Energy Efficiency for Mosque Design}

The energy used in mosques is mostly for air conditioning, lighting, electricity, and water. Air conditizConing is needed for a building in an 
uncomfortable climate condition. This condition is hard to avoid, but we can prevent the AC system load by providing a passive cooling system. Since early times, the method of using thermal phenomena for cooling buildings has been recognized[9]. It can be seen from traditional methods, such as wind towers and courtyards design, commonly used in hot-dry climates due to their capability to improve energy efficiency and maintenance cost. The example structure for a passive cooling tower is the "chimney shape" of a vertically built duct with open top-windows or openings to capture the dry, hot air from the outside. Figure 1 shows the perforated wet media used to allow the hot air to pass through and transform into cool air directed inside the Mosque. This approach can reduce the Mosque's indoor temperature when the hot air temperature is high and the humidity is low.

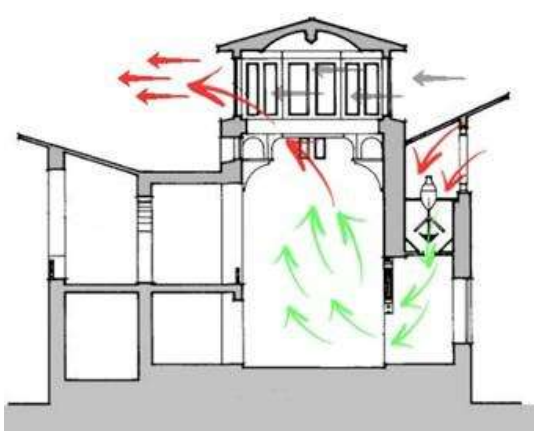

Figure 1: The example structure for a passive cooling tower system by Hassan Fat'hi

Aside from air conditioning, mosques should also be efficient in using lighting, electricity, and water. The lighting energy can be reduced by using daylight in the day by providing adequate daylight quality. A mosque can also use renewable energy technologies to save water and electricity for lighting.

A mosque can use a solar PV system as energy from the sun. Many mosques use this technology for energy saving. For example, using solar PV on the rooftop, the Riyadh Mosque Saudi Arabia's annual bill can be reduced to nearly zero under a net metering mechanism [10]. Meanwhile, Sultan Ismail Mosque's solar system can reduce UTM's electricity bill by RM 33,000 annually ( $47 \%$ reduction) [11]. Some mosques in Qatar also use PV to provide the air conditioning system of the considered Mosque with annual electricity demand the $A / C$ system. The results show that the utilization of PV for air conditioning purposes has big potential for saving the economy and environment in Qatar [12]. The same condition happens in the Mosque of Engineering Faculty of Universitas Indonesia. It has $32,19 \%-55,67 \%$ electricity energy savings consumption from utility grid [13].

Another example is the Ministry of Islamic Affairs Mosque in Kuwait. Developing a grid-connected photovoltaic solar system in the Mosque could be economically viable and provide peak shaving during peak load [14].

Meanwhile, some mosques use water treatment for energy efficiency. One of them is Sultan Ismail Mosque in UTM Malaysia that used a water cascade analysis technique to establish the minimum water targets. The result shows that the conventional system could save $25 \%$ fresh water and $19,8 \%$ wastewater. Meanwhile, the water cascade analysis technique predicted savings of $65,1 \%$ fresh water and $51,5 \%$ wastewater, up to $85,5 \%$ fresh water and $67,7 \%$ wastewater with reuse and regeneration [15]. In Johor, Malaysia, $13 \%$ of the mosques receive water supply from an alternative source, especially the rainwater harvesting system. The stored water from the system is used to wash kitchen utensils. The quality is similar to the groundwater [16]. Another water-saving technology is a self-closing tap for wuduk activity in Masjid Assiddiq Seri Iskandar Perak Malaysia. The result shows that mosque water consumption decreases and saves about RM 30 for a month [17]. Another example of water treatment is greywater treatment in the National University of Malaysia Mosque. The treatment can save water for 1,52 liter per person who prays in the Mosque [18].

Furthermore, wind can also be used for energy in mosques, such as in Aceh Indonesia [19] and Remote Mosque in Saudi Arabia Highway [20]. Mosque usually has a very tall minaret. In height, the wind speed is higher than in the ground. So we can use the minaret to be the turbine to catch the wind for the alternative energy for the Mosque.

\section{The Use of the Climate Condition for a Mosque Degnsi}

The increased height of the prayer hall would offer ventilation with high windows to the innermost areas of the deep-plan Mosque before the invention of artificial lighting [21]. These windows or other high openings often provide airflow by stack effect in hotter climates. They permitted the room to stay comfortable while the overhead sun-heated air was closer to the ceiling while the prayer area stayed relatively cold. Historically, some mosques have also been purposely built for the prayer hall with much more height than simply required lighting and ventilation. Additionally, several mosques today maintain the practice of constructing greater than necessary volumes in the main prayer hall to create a wide size.

Furthermore, the Cyberjaya Mosque in Malaysia, which uses modern materials, has an architecture and design appropriate for Malaysia's hot-humid environment that allows enough wind to move through it to provide good ventilation and thus reduce the cooling load [22]. The architecture of the Cyberjaya Mosque is unmatched by any previous type of Mosque. Its fundamental concern is creating a sustainable building that utilizes flexibility and purity in its architecture to present Islam as a secular faith. The glass dome over the enclosed main prayer hall will be equipped with LED lighting and uses Two Low 'E' 
glass panels connected to the decorative aluminum grilles used as sun-shielding devices. Moreover, the glass dome allows various light and shades to be cast each day in natural light. It makes any hour during the day for a new environment.

Another mosque that used daylight as the architectural element is Sheikh Lotfollah Mosque in Isfahan, Iran. The lighting design of the Mosque shows how daylight pervades the sequential spaces. The spaces present several appearances of daylight, controlled during different time intervals. The observation of daylight penetrations in each episode reveals that building orientation, fenestration, reflection, and daylight variability are the major factors to analyze daylight in sequential spaces [23].

Meanwhile, Orhan Gazi Mosque and Neziraga Mosque in Istanbul, Turkey, use their dome and pyramid roof to provide efficient indoor daylight. The dome mosque has a better illuminance level than the pyramid roof mosque [24]. The same thing happens in Sepahsalar Mosque in Iran. Sunlight creates spaces within the southern vault of the Mosque by establishing a combination of light, shade, and darkness [25].

\section{The Use of Sustainable Building Material for Mosque Design}

Al-Masjid An-Nabawi is a suitable example of a sustainable approach to the Mosque's design [26]. It is important because this Mosque was constructed using a simple method of construction, local materials and technology, and the well-designed flexible layout that allows for any further adjustment or modifications without hindering the surrounding. Besides, this Mosque was built without being biased by any ideas and the characteristics, materials, and technology adapted locally. Furthermore, in the past, the primary building material was picked from nature and soil material into the construction and manufacturing technique [27]. Even today, for many reasons, soil systems have become the point or object of the search for healthier changes in the construction process, and soil structures have the ability to use a sustainable material in construction. Some reasons can be; (1) Easy of purchase from nearby and local regions, (2) Simplicity of construction methods that do not require qualified craftsmanship, (3) Based on the building life cycle, the support of next-generation design techniques makes it environmentally sustainable and energy-friendly materials.

Another mosque that uses a local natural material is the Suleymaniye Mosque in Istanbul, Turkey. The primary material is generally different types of granites, marbles, limestones, pudding stones, porphyry, and serpentinite. Detachment, material loss, biological colonization, discoloration, and deposits have been determined as deterioration types on these stones [28].
In hot humid areas like Malaysia, different local materials are used for mosques. The traditional Kampung Laut Old Mosque uses timber construction techniques as the local material and construction. This Mosque is believed to be the oldest surviving timber mosque construction in Malaysia and Southeast Asia. The construction elements resemble the rich timber building design, which concerns the local culture, spiritual perspectives, and climatic approach portraying the regional identity of the built environment [29]. Another mosque around forested areas that uses timber as the main material is Bekdemir Mosque in Turkey. The Mosque uses wood in its walls, columns, and roof. Timber construction is proved to be more resistant in a seismic area [30].

\section{Indoor Air Quality in Sustainable Mosque Design}

Because Mosque is a central place for Muslims to do their religious activities, Mosque must have good indoor air quality. To stay in one place for quite a long time, people need to feel comfortable. Indoor air quality depends on the airflow behavior, the distributions of temperatures and relative humidity, and the concentration of carbon dioxide due to the high occupancy load of people. Healthy Indoor air quality can be achieved by providing good ventilation. For example, Sultan Ternate Mosque uses clerestory ventilation and cross ventilation systems to reach a comfortable level [31].

Another example is shown in an Air-conditioned mosque building in Kuwait. The mosque building show $\mathrm{CO}_{2}$ concentration considered slightly higher than the ideal $\mathrm{CO}_{2}$ concentration. It will improve ventilation rates by opening windows and doors [32]. It is proved that natural ventilation can provide better indoor air quality than air-conditioned rooms. Another research strengthens it in some mosques in Yalova, Turkey. In the naturally ventilated Mosque, opening window considerably improved the air quality but increased the indoor relative humidity. Using fans can enhance the air quality by reducing pollution in the occupied zone and improving the overall thermal sensation. The drawback of using fans was the risk of discomfort due to the peaks in airspeed caused by rotation of the fans, which must be prevented to attain comfortable conditions. Turning the air conditioning on during prayers was not an efficient strategy to improve thermal comfort. It is recommended to consider pre-cooling of the Mosque and keep air conditioners off during prayers [33]. 


\section{Socially Sustainable Mosque}

Social sustainability plays an important part as another requirement for green and sustainable approaches in mosques. The social and spiritual sustainability of the community can be increased through the religious activities conducted at the Mosque. A mosque should be designed as multifunctional and have communal space for having diverse activities and possessing community space. Mosques have been listed as the highest preference for public space. Three key qualities lead the community to choose the Mosque as the most important public space: 1) convenient access, 2) comfortable and clean, and 3) social aspects. These three keys contribute to improving quality of life, social interaction, and social cohesion to achieve the Sustainable Development Goals globally [34].

In addition to the abundance of open space inside the mosque layout, instead of a conventional green space that only fits aesthetically, an open functional green space is a perfect addition to appeal to this purpose. The green open space can also improve the cross ventilation of the Mosque, showing how sustainable and green architecture is implemented into the design of the Mosque. For example, related to Malaysia context, this space can be the center of learning and community activities such as community cook 'bubur lambuk' during the month of Ramadhan, Malay tradition of 'berkhatan' (circumcision) ceremony, and Al Quran class for children during school holidays. The impact of open green space is that it can give users comfort and create a sense of belonging when social interactions are held in green infrastructure. Hence, it will serve as a focal point for some casual social activity with green usable open space to promote social links and community cohesion and build feelings of protection.

\section{RECOMMENDATIONS}

Table 1. The suggested sustainable design strategies for mosques

\begin{tabular}{ll}
\hline $\begin{array}{c}\text { Sustainable Design } \\
\text { Principles }\end{array}$ & \multicolumn{1}{c}{$\begin{array}{c}\text { Sustainable Design Strategies for } \\
\text { Mosque }\end{array}$} \\
\hline Energy Efficient & $\begin{array}{l}\text { Solar PV } \\
\text { Wind Turbine } \\
\text { Water treatment }\end{array}$ \\
\hline Climate Condition & Daylighting \\
& Natural ventilation \\
& Thermal comfort \\
\hline Sustainable material & Local material \\
\hline Indoor air quality & Natural ventilation \\
& Daylighting \\
\hline Socially sustainable & Muslim's religious activity \\
Mosque & \\
\hline
\end{tabular}

Sustainable mosque building methods and techniques are not a recent idea in Islam. However, it has a deep and heavy origin in early Islamic architectural traditions, such as Al-Masjid An-Nabawi. Therefore, the sustainable design can be implemented from previous early mosques. Table 1 describes some strategies for mosques to achieve sustainability. The natural and passive technique saves a substantially low cooling energy rate compared to electromechanical air -conditioning devices. In addition to their costeffectiveness over the entire construction life cycle (initial and operational), these natural processes are environmentally sustainable and do not contain harmful materials. Furthermore, a sustainable and green mosque is a vibrant mosque full of green scenery, a good sense of culture, and a vibrant economy. In that regard, it is proposed that more group events, such as playgrounds or sports facilities, should be introduced into the design of the Green Mosque to draw users of different ages, especially children, as long as they are not opposed to Islamic education.

Today, different styles of mosque typology from around the world have been developed in Malaysia and around the country, causing a vast number of types of mosque typology. The mosques can be designed with the previous approach or in a more progressive and sustainable direction to launch a new design age.

\section{CONCLUSION}

This study looks into various design strategies related to green and sustainable approaches used in designing mosques in Malaysia and other countries. The value of a green building for a mosque is undeniable. To complete their worship of Allah, green technology greatly influences Muslims. As the Mosque also reflects Malaysia's real culture, each Mosque can have more green technology. To mitigate its impact on nature, it is proposed that mosques adopt ecological design schemes. The Mosque is the center where people study good deeds and perform them. Thus, a green and environmental approach to architecture will guarantee Muslims a safe and friendly atmosphere and enable them to visit and engage in mosque activities.

\section{ACKNOWLEDGMENT}

This study was supported by the Ministry of Higher Education (MOHE) through 'Fundamental Research Grant Scheme' (FRGS) (FRGS/1/2021/WABo9/ UTHM/03/1) for the research project Modenisasi Senibina Melayu Tradisional: Ekplorasi Kerangka Asas Senibina Melayu Moden (SMM) di Malaysia Berteraskan Model Peyelidikan' Research Onion'. The authors also acknowledge the support of the Architecture Department, University Tun Hussein Onn Malaysia, and WARIS Research Group, Universiti Putra Malaysia.

\section{REFERENCES}

[1] Z. M. Sharif, N. J. Jalil, and H. A. Bekhet, "Green Building, Sustainability and Mosques Design in Kuala Terengganu," International Journal of Engineering \& Technology, vol. 8, no. 1, pp. 228 234, 2019, doi: https://doi.org/10.14419/ ijet.v8i1.124664. 
[2] M. Yilmaz, "Sustainable Design in Architecture," in An International Design Conference, May 2006, pp. $1443-1450$.

[3] I. M. Lami and B. Mecca, "Assessing Social Sustainability for Achieving Sustainable Architecture," sustainability, vol. 13, no. 1, p. 142, Dec. 2020, doi: 10.3390/su13010142.

[4] S. S. Omar, N. H. Ilias, M. Z. Teh, and R. Borhan, "Green Mosque: A Living Nexus," EnvironmentBehaviour Proceedings Journal, vol. 3, no. 7, p. 53, Mar. 2018, doi: 10.21834/e-bpj.v3i7.1281.

[5] N. A. Azmi and Mohd. Z. Kandar, "Factors contributing in the design of environmentally sustainable mosques," Journal of Building Engineering, vol. 23, pp. 27-37, May 2019, doi: 10.1016/j.jobe.2019.01.024.

[6] S. Johar, A. G. Ahmad, A. I. Che-Ani, M. M. Tahir, N. A. G. Abdullah, and N. M. Tawil, "Conservation Activities of Old Traditional Mosque in Malaysia: An Overview," in SELECTED TOPICS in POWER SYSTEMS and REMOTE SENSING, Oct. 2010, pp. 269-277.

[7] F. Z. Othman, S. S. Ahmad, and N. L. Hanapi, "THE RELATIONSHIP BETWEEN VENTILATION AND OPENING STRATEGIES OF DOMED MOSQUE FOR INDOOR COMFORT," e-Academia Journal, vol. Special Issue, pp. 85-91, 2018.

[8] M. Bengtsson, "How to plan and perform a qualitative study using content analysis," NursingPlus Open, vol. 2, pp. 8-14, 2016, doi: 10.1016/j.npls.2016.01.001.

[9] N. I. Nordin and A. Misni, "A Comparative Study on the Indoor Thermal Performance of New and Old Mosques," Environment-Behaviour Proceedings Journal, vol. 2, no. 5, p. 23, Mar. 2017, doi: 10.21834/e-bpj.v2i5.677.

[10] A. M. Elshurafa, A. M. Alsubaie, A. A. Alabduljabbar, and S. A. Al-Hsaien, "Solar PV on mosque rooftops: Results from a pilot study in Saudi Arabia," Journal of Building Engineering, vol. 25, p. 100809, Sep. 2019, doi: 10.1016/ j.jobe.2019.100809.

[11] E. E. Rashid, S. R. W. Alwi, and Z. A. Manan, "EVALUATION OF PHOTOVOLTAIC SYSTEM INSTALLATION FOR A MOSQUE IN UNIVERSITI TEKNOLOGI MALAYSIA," Perintis e-Journal, vol. 1, no. Special Issue on Science for Sustainability, pp. 61-81, 2011.

[12] M. Kharseh, M. Al-khawaja, and S. Abdu Ghani, "Solar Energy For More Eco-friendly Mosque In Qatar," 2014. doi: 10.5339/qfarc.2014.EEPPo606.

[13] A. N. Mizard, D. R. Aryani, A. Verdianto, and C. Hudaya, "Design and Implementation Study of 3.12 kWp On - Grid Rooftop Solar PV System," in 2019 International Conference on Electrical Engineering and Informatics (ICEEI), Jul. 2019, pp. 465-470. doi: 10.1109/ ICEEl47359.2019.8988862.

[14] Y. B. Almutairi, "Peak Shaving Using GridConnected Solar Panels Case Study: Ministry of Islamic Affairs Mosque," International Journal of Engineering Research and Applications, vol. 4, no. 8, pp. 158-166, 2014.
[15] Z. A. Manan, S. R. Wan Alwi, and Z. Ujang, "Water pinch analysis for an urban system: a case study on the Sultan Ismail Mosque at the Universiti Teknologi Malaysia (UTM)," Desalination, vol. 194, no. 1-3, pp. 52-68, Jun. 2006, doi: 10.1016/j.desal.2005.11.003.

[16] Y. A. Eusof, M. Denny, A. P. M. Som, M. M. Jusan, and B. bin Ibrahim, "An Assessment of Green Mosque Index in Peninsular Malaysia," AmericanEurasian Journal of Agriculture and Environmental Science, vol. 15, pp. 114-122, 2015.

[17] A. F. Yusof, M. Z. Mohd Zaki, H. Ab dulHamid, and F. H. Husain, "A Study of Mosque Water Consumption using Self Closing Tap," Jurnal Islam dan Masyarakat Kontemporari, vol. 21, no. 2, pp. 238-251, Sep. 2020, doi: 10.37231/ jimk.2020.21.2.497.

[18] N. Utaberta, A. N. Handryant, and M. A. Othuman Mydin, "An Analysis of Grey Water Treatment System in the National University of Malaysia Mosque," Applied Mechanics and Materials, vol. 747, pp. 313-316, Mar. 2015, doi: 10.4028/www.scientific.net/AMM.747.313.

[19] M. Razi, N. Safitri, and B. Bukhari, "Ventilator Turbine Model Application to the Mosque Tower's Dome as Electricity Generator," Oct. 2018.

[20] H. Moria, "Techno-Economic Optimization of Solar/Wind Turbine System for Remote Mosque in Saudi Arabia Highway: Case Study," International Journal of Engineering Research \& Technology (IJERT), vol. 8, no. 9, pp. 78-84, 2019.

[21] N. A. Azmi and Mohd. Z. Kandar, "Factors contributing in the design of environmentally sustainable mosques," Journal of Building Engineering, vol. 23, pp. 27-37, May 2019, doi: 10.1016/j.jobe.2019.01.024.

[22] A. Aziz, "Execution of contemporary Islamic architecture through design: the cyberjaya green platinum mosque project in Malaysia," WIT Transactions on The Built Environment, vol. 159, pp. 11-22, 2016.

[23] M. Shahani, "Sheikh Lotfollah Mosque: A Story of Daylight in Sequential Spaces," Space and Culture, vol. 24, no. 1, pp. 19-36, Feb. 2021, doi: 10.1177/1206331218782406.

[24] Y. Arab and A. S. Hassan, "DAYLIGHT PERFORMANCE OF SINGLE PEDENTIVE DOME MOSQUE DESIGN DURING WINTER SOLSTICE," American Journal of Environmental Sciences, vol. 9, no. 1, pp. 25-32, Jan. 2013, doi: 10.3844/ ajessp.2013.25.32.

[25] S. H. Tabibian, F. Habib, and S. A. Garakani, "An Analytical Approach to the Quality of Natural Light within the Vault of Sepahsalar Mosque (Shahid Motahari School)," Naqshejahan-Basic studies and New Technologies of Architecture and Planning, vol. 9, no. 4, pp. 245-256, 2020.

[26] N. Asif, N. Utaberta, A. Sarram, and S. Ismail, "DESIGN FRAMEWORK FOR URBAN MOSQUE IN THE CITY OF KUALA LUMPUR: A QUALITATIVE APPROACH," International Journal of Architectural Research: ArchNet-IJAR, vol. 12, no. 
3, p. 170 , Nov. 2018, doi: 10.26687/archnetijar.v12i3.1586.

[27] N. A. Akyıldız and T. N. Olğun, "Investigation for Energy Use and Conservation of Sustainable Traditional Architecture: Case of Malatya/ Turkey Bahri Mosque," Architecture Research, vol. 10, no. 2, p. 6067, 2020.

[28] C. A. Bilen, S. Erisis, S. Er, M. Yilmaz, S. Angi, and A. Tugrul, "Deterioration Types of Stones Used in Suleymaniye Mosque (Istanbul, Turkey)," IOP Conference Series: Earth and Environmental Science, vol. 44, pp. 1-10, Oct. 2016, doi: 10.1088/1755-1315/44/5/052045.

[29] A. Sanusi Hassan and M. Syafik Ahmad Nawawi, "Malay Architectural Heritage on Timber Construction Technique of the Traditional Kampung Laut Old Mosque, Malaysia," Asian Social Science, vol. 10, no. 8, Mar. 2014, doi: 10.5539/ass.v10n8p230.

[30] B. Ş. Şeker and M. Özkaynak, "Seismic Assessment of Historical Timber Bekdemir Mosque," Journal of Multidisciplinary Engineering Science and Technology (JMEST), vol. 8, no. 7, pp. 1435014357, 2021.
[31] M. Rahim and F. Marasabessy, "Evaluation of Natural Ventilation Characteristics on the Sultanate of Ternate Mosque," IOP Conference Series: Materials Science and Engineering, vol. 506, pp. 1-7, Apr. 2019, doi: 10.1088/1757899X/506/1/012035.

[32] F. F. Al-ajmi, A. S. Al-ajmi, and F. A. Alrashidi, "Indoor Environmental Quality in Air-conditioned Mosque Buildings in Kuwait," American Journal of Civil Engineering and Architecture, vol. 5, no. 4, pp. 167-173, 2017.

[33] A. Yüksel, M. Arıcı, M. Krajčík, and H. Karabay, "Experimental investigation of thermal comfort and $\mathrm{CO}_{2}$ concentration in mosques: A case study in warm temperate climate of Yalova, Turkey," Sustainable Cities and Society, vol. 52, p. 101809, Jan. 2020, doi: 10.1016/ j.scs.2019.101809.

[34] N. Jaffar, N. Z. Harun, and A. Abdullah, "ENLIVENING THE MOSQUE AS A PUBLIC SPACE FOR SOCIAL SUSTAINABILITY OF TRADITIONAL MALAY SETTLEMENTS," PLANNING MALAYSIA, vol. 18, no. 12, May 2020, doi: 10.21837/pm.v18i12.750. 